\title{
Assistance in Family Health From the Perspective of Users ${ }^{1}$
}

\author{
Silvana Martins Mishima \\ Flavia Helena Pereira ${ }^{3}$ \\ Silvia Matumoto ${ }^{4}$ \\ Cinira Magali Fortuna ${ }^{4}$ \\ Maria José Bistafa Pereira ${ }^{5}$ \\ Ana Carolina Campos ${ }^{6}$ \\ Vanessa Garcia de Paula ${ }^{7}$ \\ Maria Márcia Leite Nogueira Domingos ${ }^{7}$
}

This descriptive exploratory study analyzed user satisfaction with the care received at a Family Health Unit in Ribeirão Preto, Brazil. In total, 40 users from families registered in the FHU were selected, using key informants and the snowball sampling technique, and interviewed. Thematic content analysis was used to analyze the empirical material. Interviewees were mostly female, over 50 years, resident in the catchment area of the unit for 10-30 years, had incomplete primary education and also did not perform work outside the home. The analysis identified three themes: access, team-user interaction and organization of work in the FHU. The subjects of this study expressed satisfaction with the accessibility provided together with the caring attention given to them, marked by a team-user interaction that takes place in a friendly and patience manner. Although not totally satisfied, the majority of users would recommend the health service to someone due to its quality.

Descriptors: Family Health; Primary Health Care; Patient Satisfaction; Basic Health Services.

\footnotetext{
${ }^{1}$ Supported by CNPq, Process \# 301443/2006-8.

Escola de Enfermagem de Ribeirão Preto, Universidade de São Paulo, WHO Collaborating Centre for Nursing Research Development, SP, Brazil:

${ }^{2}$ RN, Ph.D. in Nursing, Full Professor. E-mail: smishima@eerp.usp.br.

${ }^{3}$ RN, Master's Student. E-mail: flaenf2003@hotmail.com.

${ }^{4}$ RN, Ph.D. in Nursing, Faculty. E-mail: smatumoto@eerp.usp.br. E-mail: fortuna@eerp.usp.br.

${ }^{5}$ RN, Free Lecture, Associate Professor. E-mail: zezebis@eerp.usp.br.

${ }^{6}$ RN, Master's Student. E-mail: caroltiana@yahoo.com.br.

7 Master's Student. E-mail: nessagp@terra.com.br. E-mail: marciadomingos@usp.br.
}

Corresponding Author:

Silvana MArtins Mishima

Universidade de São Paulo. Escola de Enfermagem de Ribeirão Preto

Av. Bandeirantes, 3900

Bairro Monte Alegre

CEP: 14040-902 Ribeirão Preto, SP, Brasil

E-mail: smishima@eerp.usp.br 


\section{A assistência na Saúde da Família sob a perspectiva dos usuários}

Analisou-se satisfação do usuário quanto ao atendimento em uma Unidade de Saúde da Família (USF) em Ribeirão Preto, SP, Brasil. É um estudo exploratório descritivo. Foram entrevisados 40 usuários de famílias cadastradas pela USF, selecionados a partir de informantes chave e da técnica snowball para amostragem. Para análise do material empírico, utilizou-se análise de conteúdo na modalidade temática. Os entrevistados são majoritariamente mulheres, acima de 50 anos, residentes na área de abrangência da unidade, de 10-30 anos, possuíam ensino fundamental incompleto e também não exerciam trabalho fora do domicílio. A análise identificou três temas: acesso, interação equipe/usuário e organização do trabalho na USF. Os sujeitos deste estudo expressam satisfação com a acessibilidade desde que aliada à atenção cuidadosa que lhes é dispensada, marcada por interação equipe/usuário que se produz de forma amigável e pacienciosa. Embora não totalmente satisfeitos, a maioria dos usuários indicaria esse serviço de saúde a alguém, por sua qualidade.

Descritores: Saúde da Família; Atenção Primária à Saúde; Satisfação do Paciente; Serviços Básicos de Saúde.

\section{La asistencia en la Salud de la Familia bajo la perspectiva de los usuarios}

Este estudio exploratorio y descriptivo analizó la satisfacción del usuario en lo que se refiere a la atención recibida en una unidad de Salud de la Familia(USF) en Ribeirao Preto-SP, Brasil. Fueron entrevistados 40 usuarios de familias registradas por la USF, seleccionadas por informantes clave y muestreo por bola de nieve. El análisis temático de contenido se utilizó para analizar el material empírico. Los entrevistados son mayoritariamente mujeres, con más de 50 años, residentes en el área de alcance de la unidad, entre 10 y 30 años, tienen enseñanza primaria incompleta y no ejercían trabajo fuera del domicilio. El análisis identificó tres temas: acceso, interacción equipo-usuario y organización del trabajo en la USF. Los sujetos del estudio expresaron satisfacción con la accesibilidad desde que vinculada a la atención cuidadosa que recibían, marcada por una interacción equipo-usuario amigable y paciente. A pesar de que no están totalmente satisfechos, la mayoría de los usuarios indicaría este servicio por su calidad.

Descriptores: Salud de la Familia; Atención Primaria de Salud; Satisfacción del Paciente; Servicios Básicos de Salud.

\section{Introduction}

The Family Health - FH, strategy adopted by the Ministry of Health of Brazil, has been implemented throughout the country since 1994, in order to make changes to the logic of the current, biomedical, curative, individualizing, action fragmenting model of care. In this period of implementation, one of the criticisms elaborated refers to the maintenance of its core work, still doctorcentered, which does not qualitatively change the profile of services and acts only on the structure of services and not on the work process ${ }^{(1)}$
For this change of logic in the work process in $\mathrm{FH}$, there is a need for actions that make it possible to work with individual and collective care, including actions for harm prevention, health promotion, as well as those related to the organization of the work process and that implicate the monitoring and evaluation of the care

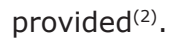

The evaluation of health services is an area of knowledge and practice that may offer guidance and options for the planning process, which could favor the 
technical and social control of the services provided to society. Studies(3-8) on the evaluation of health services, of programs and of specific actions have been produced, however, there is still a scarcity of scientific production focused on user satisfaction concerning the Primary Health Care (PHC) services, especially those related to Family Health ${ }^{(9-13)}$, thus, this research can contribute to the reflection and production of knowledge in this field of practice.

In the evaluation of health services, considered a process of judgment of the characteristics of services, the participation of all actors involved in the provision of health care must be considered, emphasizing the purpose of the services, directed, ultimately to the attention to problems and needs of users, and in this sense, the analyses of users concerning the health services should be recognized as containing rationality and should be analyzed in the historical and social context of their production(12). Thus, it is understood that the evaluation of satisfaction/dissatisfaction by the users of health services is an important tool to support the process of shared decision making in order to re-think the professional practices, re-organize the developed work process, re-allocate resources, readjust actions and redefine goals that are consistent with the established political project ${ }^{(5,12,14)}$.

In this context, the discussion about the quality of health services in Brazil is complex. In its interface with quality, the evaluation of user satisfaction is also a challenging task, since the provision of services does not happen in a homogenous way. The Brazilian territory is marked by specificities, by heterogeneity of the population, by the differentiated inclusion in society of the subjects that compose this population and by the distinct conditions of life. These determine different forms of being unwell and of being healthy, and, therefore of using the health services. These services should organize themselves to better respond to local needs of their populations, including regional organization in relation to the services of medium and high complexity Additionally, there are also the specific demands, loaded with expectations and the subjectivity of the users, differentiated by their socio-economic and cultural insertion ${ }^{(6)}$.

Scholars of the theme have highlighted the diversity of theoretical and methodological approaches found in the investigations of user satisfaction, and that "there are important differences in the activation of the concept of satisfaction, i.e. in the definition of its components or dimensions $[\ldots]^{\prime \prime(15)}$, which relate to aspects of services, such as: access, quality, physical and organizational structure, aspects of the doctor-patient relationship, among others ${ }^{(15)}$.

In this research the following dimensions of satisfaction were used for the analysis of user satisfaction regarding the assistance provided by a Family Health Unit: relational (respect, consideration, welcome, kindness, concern, friendliness, courtesy), organizational (organization of the services), professional (time spent in consultation, sufficient and clear information, communication between the professionals and the users), socio-economic (aspects related to the living conditions of people), cognitive (user conception, understanding of the logic of operation of the service) ${ }^{(8,15)}$.

Considering this set of aspects, this study aimed to analyze the satisfaction of users of a Family Health Unit of the Ribeirão Preto - São Paulo - Brazil, with respect to the assistance provided.

\section{Study route}

This was a descriptive, qualitative study carried out in Ribeirão Preto - São Paulo - Brazil, which has a large public network of provision of PHC services and specialized services of different levels of care. In 2005, when the study was carried out, the city had 14 Family Health teams.

The FHU selected had been in operation since April 2001 , its coverage area is divided into five micro-areas*, with an approximate population of 3,148 people or 787 registered families, being a unit in which the University of São Paulo maintains teaching, research and service extension activities.

For data collection semi-structured interview were held, consisting of general questions relating to the characterization of the interviewee, and other questions aimed at the use the service, such as: reason for seeking health services, possibility of attention in other public services, ease of medical and nursing attention, waiting time, information provided, knowledge of the activities offered, the occurrence of problems arising in the care received at the Health Unit, as well as suggestions for improving the care provided.

The study subjects were individuals aged 18 or over, present in the domicile when the interview was carried out. Data were collected from January to February 2006 and the sample consisted of 40 interviewees, being one from each domicile, originating from the five micro-areas. These users were selected according to the chain sampling technique (snowball)(16), i.e. from the identification

* The micro-area is considered one territorial unit homogeneous in the population distribution and in the risks and vulnerabilities of its population, each micro-area being the responsibility of a Community Health Agent. 
and location of an initial group of interviewees with determined characteristics, who also constitute the informants for the identification of other subjects with the same characteristics to be included in the research, this process being repeated successively in order to identify the largest number of individuals that could contribute to the study ${ }^{(17)}$. Thus, to carry out the process of selection of research subjects, initially, the Community Health Agents of the FHU, here considered key informants, were asked to indicate five people per micro-area of the FHU that could express their perception of the care provided by the FHU. From these five users, one for each micro-area was randomly chosen, and thus became the starting points for the interviews. In the final definition of the sample the criterion of exhaustion was considered, i.e. when the data from the set of semi-structured interviews began to repeat in its entirety. There was no refusal to participate and all interviewees indicated at least one other resident.

Of the 40 interviewees, 37 were women and three men. This situation was also found in other studies, possibly due to the social role historically assumed by the woman as the carer of the family, being most easily found in the domicile(5). There was great variation in time of residence among the interviewees, varying from three months to 40 years and more. It is important to note that $26(65 \%)$ had resided in the area covered by the FHS for 10 to 30 years and four (10\%) for over 40 years, which showed that they were people who circulated through this territory and in some way, knew or had heard about the health services that exist. Of those interviewed, three (7.5\%) were illiterate, 21 $(52.5 \%)$ had incomplete primary education and two $(5 \%)$ complete university education, which indicates a low level of education among the subjects interviewed. Concerning occupation, 21 (52.5\%) were housewives, 10 $(25 \%)$ retirees or pensioners, three $(7.5 \%)$ salespeople, three $(7.5 \%)$ maids, one $(2.5 \%)$ a teacher, one $(2.5 \%)$ a hairdresser and manicurist, and one (2.5\%) a cleaner, $77.5 \%$ of research subjects, were not engaged, at the time of data collection, in any work outside the domicile.

Regarding age, 20 (50\%) were over 50 and 16 $(40 \%)$ over 55 years old. It is worth noting that older people and "elderly tend to be more satisfied with health services than younger people"(7), since the use of these services can have a significance of a search for satisfaction of other needs, not just resolution of a health problem expressed as a condition or set of signs and symptoms.

The interviews were taped with the consent of the respondent according to the regulations of Resolution CNS
196/96, and Chapter IV of Resolution 251/97, the study was approved by the Research Ethics Committee of the Health School Center of the Faculty of Medicine of Ribeirao Preto, USP, under the protocol CSE-FMRP-USP 0161.

For the data analysis of the variables focused on the general characterization of the research subjects, we designed a database with the using the software Excel, verifying the simple frequency of the variables. The qualitative aspects were analyzed according to thematic content analysis(18), searching for convergences, divergences, and the unusual, in the words that originated from the interviews. In the process of analysis three themes were identified: access to the FHU, user interaction with the team, suggestions for the organization of the FHU.

\section{Results and discussion}

\section{Access to the Family Health Unit - expression of satisfaction and contradictions}

The historical process of the approaches in the area of PHC indicates "the emergence of care as a mechanism for expanding access to services essential for maintaining the health of individuals"(5). Primary Health Care as the primary level of care, linked to other levels, presupposes the construction of an integrated network of health services being, the one which functions as a gateway to the system of care, over time, for the needs and health problems of the people (not directed only to infirmity), coordinating or integrating the other types of attention provided at some point in the health system ${ }^{(5)}$. Thus, access refers to the possibility of using the health services when necessary, and expresses characteristics of the supply that facilitates or obstructs the possibility of people using health services when they need them. The provision of services and their geographic distribution, the availability and quality of human and technological resources, the financing mechanisms, the assistance model, and information about the system are characteristics of the supply that affects access ${ }^{(19)}$.

One of the recurrent points in the interviews referred to ease of access to the FHU. The proximity to the domicile of people was identified as one of the reasons for their choice of the unit: Ah, because it close to my house right?.. Interviewee 6. This aspect was also identified in a study conducted at a FHU in the state of Bahia, where the users pointed out the ease of access "to the professional and to the health care actions when compared to the old model of care" ${ }^{(8)}$. 
The attention to the first contact, attribute of the PHC refers to the characteristics of accessibility to the units, i.e. the time of availability, ease of public transportation, facilities for disabled people, possibility to book appointments and waiting time for them, absence of language and other cultural barriers. Accessibility enables people to enter the services, being a structural and necessary element for primary care, so the site should be easily accessible and open ${ }^{(20)}$.

Besides the proximity to the domicile, there was recognition by interviewees as to that being their Health Unit of reference, i.e. there was an expression of the concept of area of coverage of the unit, of the principle of regionalization in the organization of services that comprise the National Health System - (Sistema Único de Saúde - SUS): Ah, because it's next to my house, right, and I' $m$ from that Center. Interviewee 6. At the same time that there was this recognition, interviewees mentioned the issue of the gateway, i.e. for them to enter the health system, they have to be initially attended at FHU. Although not "complaining" about this situation, they reported it necessary to go through the FHU: ... because I have to go there first right? For me to be seen at Cuiabá. Because if I do not go there they do not see me at Cuiabá right? Interviewee 25. The statement may indicate the dissatisfaction of the user concerning the existence of the imposition of regulatory mechanisms in their access to the health services. These aspects express the organizational and cognitive dimensions of satisfaction ${ }^{(8,15)}$.

Another aspect identified as positive by interviewees was the possibility of care being given in the domicile in situations that prevent the movement of the user. Also, the system of consultations/activities scheduled was positively valued: ...I get there, and it is always with an appointment, right? It is programmed, it is scheduled. Interviewee 28. Interviewees considered that with the appointments they did not face delays in consultations, being: Very punctual, make the appointment, I get there, it's very, very punctual. Interviewee 4 . They highlighted the delay, as expected to some extent, in the development of care: It takes longer with the medical consultation because it is deeper. Interviewee 7

This waiting time at the FHU was considered satisfactory in relation to that which the user has had in other health units: Oh, because it is better than in Cuiaba. It's faster, you go there and do not stay waiting so long like there in Cuiaba, right? It's a scheduled appointment as well. Interviewee 30. This issue was different to that found in a study in Bahia( ${ }^{(8)}$, where the waiting time for consultations was still very long according to reports from users.
It is worth mentioning the reference regarding access in the interviewees' statements, when they said that this was affected by lack of alternative, because they were not able to pay for medical insurance, or lost the ability to afford insurance: ...I go because I have no insurance, right? Because if I had insurance I would not go, I would leave to those who need. Interviewee 32

In a way, there is a the clarification of an imaginary that the FHU is for someone who is unable to obtain another type of health care, disrupting the concept of universality, a principle of SUS ... it helps the community a lot, there are a lot of people [...] who have no kind of insurance [...], then it helps a lot. Interviewee 11. This issue was repeated when they claimed that they would only recommend the FHU if there was no another option: Ah, if they do not have insurance, I recommend. Interviewee 32.

On the other hand, users were identified that, even having health insurance, have opted to use the FHU, because they like the assistance given, they feel "better treated" and with faster access: It is much better to be treated here than to use the insurance, my father told me about it (intonation), [...] he pays San Francisco. There I've got appointments and tests much faster than him. Interviewee 10. An interesting aspect in these statements, referred to the fact that the FHU provides assistance to all and any person, regardless of origin and social class, being that any person can be cared for equally by the health team, presenting the principle of universality of care: [..] there is poor, there is middle class, we know that a beggar goes there, the girls treat everyone equally, there don't have rich, don't have black, don't have anything ... everybody's equal. Interviewee 10 .

However, there was an explicit contradiction in the recognition of universality when it was pointed out that at the FHU the users were not considered citizens with rights, since they had to wait for being poor, because they had no insurance, by not working, giving them an understanding of disrespect of the government for this user: ... I think that the person, looks like they do not have much respect for citizens who do not... I think we feel this prejudice, it seems that you're not working, you go to the government, is the service of the government, [...] you cannot afford to pay for a consultation, you have to stay there, you have to wait, understand, you wait, we sit there waiting, waiting, sometimes we're tired, but have to wait, you are ill, but you have to wait, I think this complaint is constant there. Interviewee 5

For the users interviewed, the relationship between public and private was explicit, showing the presence of different models of care, the public system characterized as focusing on the poor and excluded being present on one 
side, and on the other the private directed toward those who have the possibility of, directly or indirectly, financing their health care, "according to the valorization of meanings that reaffirm the supremacy of the private sphere over the public, placing the first within the sphere of quality in the direct negation of the second"(21).

This set of statements indicated the presence of organizational, cognitive and socio-economic dimensions of users' satisfaction. These dimensions were drawn from the components related to access to the services characterized by the proximity of the health unit to the domicile; ease and speed of care in relation to other health services; appropriate waiting time; care given to the people, without distinction of race, color or social class, but at the same time pointing out the contradictions present in the health system in the relationship between public and private.

\section{The interaction of the user with the team}

The interaction between the user and the team is described as, both, the expectation of "good meetings" that the user hopes to have in the health unit and, as the dissatisfaction of the relationship that is constructed, mainly with the doctor. The first aspect to note referred to the clinic being open and "to the demands of the population", giving the support possible: ...it is in a way, trying to care for us with the most support possible within their conditions. Interviewee 2 .

There was recognition that the health care team provides care for the users, and that the workers are friendly and patient: ... they are very friendly, treat people well, I think they know all the people that participate there at the center. Interviewee 31.

They reported to consider the doctors good and reliable, being that they are always correct in the care given; also that the welcome in the reception of the unit, was characterized as being caring with the users that seek health services: [...] always smiling, I think the important thing is that [...] arrive at a place to get care, you're already feeling bad and if the person comes to attend you with an angry face, but they do not, they are always smiling joking. Interviewee 6. There was reference to care with a smile, creating a more welcoming environment considering the pain and suffering that the user may be expressing. Attention, patience, trust, correct prediction of feelings and happiness, make up a set of essential elements for user satisfaction, For all the good that is there [...] I wish there were more Centers, right, then they could divide... (laughs) ... it was a blessing that for us. Interviewee 22. The relational dimension of user satisfaction ${ }^{(8,15)}$ is also present there.
However, there were expressions of dissatisfaction with medical care and some users said they did not like the doctors but liked the students, and they would not recommend the FHU because of the medical care: Because of Dr. X. I would not recommend then ... they are very nice, very attentive with us, the doctor and everyone, but they still do not do enough. Interviewee 13.

This "not doing enough" was demonstrated as a distant and authoritarian attitude of the professional felt by the user: So, there are doctors that want to give us orders, if they say you have to do it this way, you have to do like that, they do not understand you, don't understand us. Interviewee 17. It is not only the attitude of the doctor that is perceived as careless towards the user. The lack of understanding and knowledge of the user in relation to the routine of the unit, to the way work is organized, and especially the rigidity in this organization, makes the user feel not cared for, not respected: Ah, he went to be attended, he had a urinary tract infection and severe pain, but then he went also a bit out of the time, because there they have that daily routine, you know, is not like that when you feel the pain you go there, then either you go early in the morning or you go in the afternoon after one thirty, and he went in between these periods I think it was a little after ten something like that, then he wasn't able to be seen, he stayed there a while it was almost midday and he hadn't been seen, he gave up and went to look elsewhere. Interviewee 11. The rigidity and inflexibility of the health service and its workers, identified with "certain caution" by the user highlighted the difficulties concerning the feeling of being welcome, of having the pain identified and treated, which leads to the search for alternative forms of care. There was, therefore, the expression of the organizational, relational and professional dimensions of the satisfaction expressed by users ${ }^{(8,15)}$.

Even considering these aspects, in the team-user interaction, they considered that the team tries to give attention to their problems, and maintain a caring attitude, generating "good meetings" when they seek the service. These aspects were also observed in other studies $^{(5,8-9)}$, where the users expressed satisfaction in relation to the relational dimension, emphasizing respect, consideration, listening, understanding, acceptance and kindness on the part of the team professionals. On the other hand, as already pointed out, there was also a perception that the team at times does not consider their complaints important, and they criticize the authoritarian attitude often assumed by the doctor, causing dissatisfaction with the care provided. 
The suggestions about the organization of the Family Health Unit

The aspects related to the infrastructure of the FHU compromise the way the users perceive the unit. Cleanliness was identified as a problematic point, and there should be more care with this aspect, as it is a health service: And the dirt. Outside it is very dirty. Interviewee 32

The users pointed out that the FHU should provide meetings open to the public, where health concerns could be addressed, and also diseases could be talked about: [...] You discuss, like down there [...] they participate, my mother also goes because she participates in the other. She says that there are diseases there that they never knew, she learned, about drugs, [...] They already even got the Police Lieutenant[...]That's good for us, right? Mainly because if you are a housewife, you're a bit lost, right?. Interviewee 32. Although this aspect has been highlighted, other statements indicated the existence of educational and group activities developed by the unit, however, call attention to the lack of information about such activities at the $\mathrm{FHU}$, such as educational groups (pregnant women, diet reeducation) or those focused on coexistence and community participation.

There was a suggestion from users in relation to the possibility of having a dentist at the FHU: So, I would like this, to have a dentist for us to have our teeth treated ... Interviewee 37. The $\mathrm{FH}$ expects to have a dentist as a member of the basic team, allowing access to treatment dispensed by this professional, in addition to expanding access to the activities of prevention and promotion of Oral Health. However, there is still no effective presence of Oral Health in the set of PHC services, especially in $\mathrm{FH}$, generating an expression of dissatisfaction of the users when they highlight the importance of the presence of the dentist and of the existence of strategies and mechanisms that facilitate the access and adequate flow for the population to this specific care $\mathrm{e}^{(8-9,11)}$.

The dispensing of medication was highlighted as necessary in the FHU, as this procedure is currently performed in the District Unit, in view of the small geographical distance between the two units. It should be noted that other studies have pointed out this same

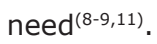

Functioning throughout the day, including Monday to Saturday was another suggestion of users: I think that they should open on Saturday, right? Because to close on Friday and only open Monday is too long. Interviewee 34. They stated that the unit should schedule and attend up to $5.00 \mathrm{pm}$ in order to assist everyone, and to not interrupt the activities before this time. This statement certainly refers to a culture that exists today in our society that health care and medical care, more specifically, is provided continuously, operating 24 hours without, however, considering other aspects relevant to being healthy. In a certain way, there is a culture to strengthen the current model of care that still focuses strictly on the treatment of the disease. However, it is important to also consider that the need for expansion and flexibility of working hours of the health unit, expressed by the users, may indicate the need for adequacy of services to care for the working population, increasing the possibilities of access.

Thus, users indicated their dissatisfaction with the organization of work in the FHU in relation to the unkempt appearance (dirty), absence of certain actions that could facilitate and expand the services provided, and inflexibility in the rules of operation of the health unit making access difficult. Although they reported difficulties in attendance, in general, most interviewees would recommend the FHU to people they know primarily due to them considering the team competent and the quality of care offered.

\section{Final considerations}

Although there are restrictions in their use, studies focused on analysis of user satisfaction are extremely important as a measure of care quality. Such studies may provide clues to the success or difficulties of health services in meeting the expectations and needs of users, becoming an important tool for research, administration and planning of health services, enabling the organization of care most appropriate to the needs and demands of clients; thus considering the importance of the subjective processes that are present in the care and evaluation process.

These issues were presented in the statements of the subjects of this study when highlighting the ease of accessibility to health services as a positive aspect since it combined with the caring attention that it provided, marked, thus, by a team-user interaction produced in a friendly and patient way, conferring a caring attitude on the part of the team.

These findings create a reflection on the need for health care and for nursing going beyond the technical and organizational aspects involved in the provision of care, indicating the need to introduce changes in the processes of formation and training of health workers and in the relationships established in the work of attention to the clients. In this sense, the results of this study 
corroborate those of others that have shown the potential of actions centered on the expectations and needs of the users towards the improvement of the quality and the humanization of care that will certainly require new concepts of "gateway" of the services, expressed, for example, in the welcoming and bonding.

It is believed that the processes of evaluation of user satisfaction in the public health services can serve as instruments to "give voice" to the users, allowing them, opportunities of expression in which they can monitor and control the activities of these services. This would strengthen their participation in the processes of planning and exercising social control, enable the construction of joint alternatives - health services and users - for the most appropriate interventions for the problems presented in the quotidian functioning of the services and enable advances in the scope of production of care and management of the health services and nursing.

\section{References}

1. Merhy EE, Franco TB. Programa de Saúde da Família: somos contra ou a favor? Saúde em Debate. 2002 abril; 26(60):118-22.

2. Giovanella L, Escorel S, Mendonça MHM. Porta de entrada pela atenção básica? Integração do PSF à rede de serviços de saúde. Saúde em Debate. 2003 setembro/dezembro; 27(65):278-89.

3. Zanetti ML, Otero LM, Biaggi MV, Santos MA, Péres DS, Guimarães FPM. Satisfaction of diabetes patients under follow-up in a diabetes education program. Rev. Latino-Am. Enfermagem. 2007 August; 15(4):583-9.

4. Paiva SMA, Gomes ELR. Hospital care: assessment of users' satisfaction during hospital stay. Rev. Latino-Am. Enfermagem. 2007 October; 15(5):973-9.

5. Ibañez N, Rocha JSY, Castro PC, Ribeiro MCSA, Forster AC, Novaes MHD, et al. Avaliação do desempenho da atenção básica no Estado de São Paulo. Ciênc Saúde Colet. 2006 julho/ setembro; 11(3):683-703.

6. Vaitsman J, Andrade GRB. Satisfação e responsividade: formas de medir a qualidade e a humanização da assistência à saúde. Ciênc Saúde Colet. 2005 julho/setembro; 10(3):599-613.

7. Souza EM, Pereira MG. A satisfação dos usuários na avaliação dos serviços de saúde. Bras Méd. 1999; 36(1/2):33-6.

8. Trad LAB, Bastos ACS, Santana ED, Nunes MO. Estudo etnográfico da satisfação do usuário do Programa de Saúde da Família (PSF) na Bahia. Ciênc Saúde Colet. 2002; 7(3):581-9.

9. Gaioso VP, Mishima SM. User satisfaction from the perspective of acceptability in the family health scenario. Texto ContextoEnferm. 2007 October/December; 16(4):617-25.

10. Halal IS, Sparrenberger F, Bertoni AM, Ciacomel C, Seibel CL, Lahude FM, et al. Avaliação da qualidade de assistência primária saúde em localidade urbana da região sul do Brasil. Rev Saúde Pública. 1994 abril; 28(2):131-6.
11. Ministério da Saúde (BR). Secretaria de Políticas de Saúde. Departamento de Atenção Básica. Avaliação da implementação do Programa Saúde da Família em dez grandes centros urbanos: síntese dos principais resultados. Brasília (DF): MS; 2002.

12. Shimizu HE, Rosales C. Family perspective on a family care program. Rev. Latino-Am. Enfermagem. 2008 October 16(5):883-8.

13. Trad LAB, Bastos ACS. O impacto sócio-cultural do Programa de Saúde da Família (PSF): uma proposta de avaliação. Cad Saúde Pública 1998 abril-junho; 14(2):429-35.

14. Donabedian A. La calidad de la atención médica: definición y métodos de evaluación. México: La Prensa Médica Mexicana; 1980.

15. Esperidião $M$, Trad LAB. Avaliação de satisfação de usuários. Ciênc Saúde Colet. 2005 setembro-dezembro; 10(supl 0):303-12.

16. Ramiro L, Matos MG. Percepções de professores portugueses sobre educação sexual. Rev Saúde Pública. 2008 Ago; 42(4):684-92.

17. Malhotra NK. Pesquisa de Marketing: Uma Orientação Aplicada. Porto Alegre: Bookman; 2001.

18. Minayo MCS, organizadora Pesquisa social: teoria, método e criatividade. Petrópolis (RJ): Vozes; 1993.

19. Travassos C, Oliveira EXG, Viacava F. Desigualdades geográficas e sociais no acesso aos serviços de saúde no Brasil 1998 e 2003. Ciênc Saúde Colet. 2006 outubro-dezembro; 11(4):975-86.

20. Starfield B. Atenção Primária: equilíbrio entre necessidades de saúde, serviços e tecnologia. Brasília (DF): UNESCO; 2002. 21. Acioli GG. A saúde no Brasil: cartografias do público e do privado. São Paulo (SP): Hucitec; 2006. 